\title{
sciendo
}

\author{
Current Issues in Pharmacy and Medical Sciences
}

Formerly ANNALES UNIVERSITATIS MARIAE CURIE-SKLODOWSKA, SECTIO DDD, PHARMACIA

journal homepage: http://www.curipms.umlub.pl/

\section{Antioxidant and antiproliferative activities of the $n$-butanol extract of Centaurea maroccana Ball aerial parts}

\author{
Imen Aissous ${ }^{1}$, Mouad Benrebai $^{1}$, Ercan Cacan ${ }^{2}$, Berkel Caglar ${ }^{2}$, Ramazan Erenler ${ }^{3}$, \\ Souad Ameddah ${ }^{1}$, Samir BenayaChe ${ }^{4}$, Fadila Benayache ${ }^{4}$, Chawki Bensouici ${ }^{5 *}$ (c) \\ ${ }^{1}$ Laboratory of Biology and Environment, Faculty of Sciences of Nature and Life, University of Mentouri Constantine 1, Constantine, \\ Algeria \\ 2 Tokat Gaziosmanpasa University, Department of Molecular Biology and Genetics, Tokat, Turkey \\ ${ }^{3}$ Tokat Gaziosmanpasa University, Faculty of Arts and Sciences, Department of Chemistry, Tokat, Turkey \\ ${ }^{4}$ Valorization of Natural Resources Unit, Bioactive Molecules and Physicochemical and Biological Analysis (VARENBIOMOL), University \\ of Mentouri Constantine 1, Constantine, Algeria \\ ${ }^{5}$ Biotechnology Research Center (CRBt), Ali Mendjli, Constantine, Algeria
}

\begin{tabular}{|c|c|}
\hline ARTICLE INFO & ABSTRACT \\
\hline $\begin{array}{l}\text { Received } 08 \text { May } 2020 \\
\text { Accepted } 10 \text { October } 2020\end{array}$ & $\begin{array}{l}\text { The aim of the present study is to evaluate the total phenolic contents, antioxidant and } \\
\text { anti-proliferative activities of the } n-\mathrm{BuOH} \text { extract of Centaurea maroccana (BECM). }\end{array}$ \\
\hline $\begin{array}{l}\text { Keywords: } \\
\text { Centaurea maroccana, } \\
\text { phenolic contents, } \\
\text { antioxidant activity, } \\
\text { anti-proliferative activity. }\end{array}$ & $\begin{array}{l}\text { The total phenolic and flavonoid of the butanolic extract of the plant were assessed by } \\
\text { using Folin-Ciocalteau and aluminium chloride colorimetric assays, respectively, and the } \\
\text { quantitative estimation of total flavonoids and phenols revealed the richness of the extract } \\
\text { in these compounds. Antioxidant activity was evaluated using standard lab colorimetric } \\
\text { methods, while the anti-proliferative activity was evaluated using sulforhodamine B } \\
\text { (SRB) assay against C6 (Rattus norvegicus brain glioma) and HT29 (Homo sapiens } \\
\text { colorectal adenocarcinoma) cell lines. The } n \text {-butanolic extract of Centaurea maroccana } \\
\text { showed a strong antioxidant activity through DPPH, ABTS }{ }^{\circ} \text {, DMSO alkalin, Reducing } \\
\text { power, } \beta \text {-Carotene-linoleic acid and CUPRAC assays. Furthermore, the anti-proliferative } \\
\text { activity against C6 and HT } 29 \text { of Centaurea maroccana exhibited a high effect by the } \\
\text { decrease in viability of both cancer cell lines. Our results suggest a possible use of } \\
\text { Centaurea maroccana as a source of natural antioxidant and chemo-preventive agents } \\
\text { against cancer. }\end{array}$ \\
\hline
\end{tabular}

\section{INTRODUCTION}

Antioxidants are inhibitors of the oxidation of an oxidizable substrate while at relatively low concentrations when compared with the substrate [1]. Preventing diseases caused by free radicals and preserving human health are the most vital roles of antioxidants [2]. Antioxidants, especially phenolic compounds, are abundant in several medicinal plants [3], where polyphenols are the most common present secondary metabolites [4]. In recent times, phenolic compounds of natural origin have been investigated, as their indirect antioxidant activity may lead to oxidative stress reduction [5].

About the Mediterranean zone and West Asia, the genus Centaurea is represented by approximately 500 species [6]. In Algeria alone, 47 species of this genus are common [7].

\footnotetext{
* Corresponding author

e-mail: chawkiislam@yahoo.fr
}

In some countries, various species of Centaurea plant have been exploited in folk medicine to treat several diseases [8]. This is the outcome of recognizing their significant biological activities [9]. Among these are: antioxidant activity [10], anti-inflammatory [11], and antimicrobial [12] antiviral, antibacterial, and antifungal [13] and cytotoxic [14] activities. In addition, several Centaurea species are considered to be valuable sources of bioactive secondary metabolites, particularly, flavonoids and sesquiterpene lactones [15] - which are significant chemotaxonomic indicators [16].

Centaurea maroccana is an endemic herb in the north of Algerian Sahara [17], thus, the aim of the present study was to assess the in vitro antioxidant and the anti-proliferative activities of an $n-\mathrm{BuOH}$ extract of Centaurea maroccana (BECM) and to correlate the results with the total phenolic content and the amount of flavonoids through colorimetric methods. 


\section{MATERIALS AND METHODS}

\section{Plant material}

Centaurea maroccana was collected from the area of Biskra in the South of Algeria and authenticated by Prof. M. Kaabeche (Biology department, University of Setif, Algeria) according to Quezel and Santa [18]. A voucher specimen (CCM12/04/02) was then deposited in the Herbarium of the Biology Department of Mentouri University of Constantine.

\section{Extraction}

Air-dried aerial parts (leaves and flowers, $2700 \mathrm{~g}$ ) of Centaurea maroccana were powdered (slight grinding with controlled temperature, up to $35^{\circ} \mathrm{C}$ ) and macerated at room temperature with $\mathrm{MeOH}-\mathrm{H}_{2} \mathrm{O}(80: 20, \mathrm{v} / \mathrm{v})$ three times $(24$ hours for each time). The filtrates were combined, concentrated under reduced pressure (up to $35^{\circ} \mathrm{C}$ ), diluted in $\mathrm{H}_{2} \mathrm{O}$ (1000 ml) under magnetic stirring and maintained at $4^{\circ} \mathrm{C}$ for one night to precipitate a maximum of chlorophylls. After filtration, the resulting solution was successively extracted with solvents with increasing polarities: chloroform $\left(\mathrm{CHCl}_{3}\right)$, ethyl acetate (EtOAc) and n-butanol $(n-\mathrm{BuOH})$. The organic layers were dried with anhydrous $\mathrm{Na}_{2} \mathrm{SO}_{4}$, filtered and concentrated under vacuum at room temperature to obtain $\mathrm{CHCl}_{3}$ (12.5 g, yield: 0.46\%), EtOAc (20 g, yield: 0.74\%) and $n$ - $\mathrm{BuOH}$ (40 g, yield: $1.48 \%$ ) extracts. A part of the Centaurea maroccana $n$-BuOH extract (designated BECM) was used in the current study.

\section{Spectral measurements and chemicals used}

The measurements and calculations of the activity results were established by using a 96-well microplate reader (PerkinElmer Multimode Plate Reader EnSpire, USA) at the National Center of biotechnology Research. The chemical products and reagents used were: Folin-ciocalteu's reagent (FCR), 1,1-diphenyl-2-picrylhydrazyl (DPPH), butylatedhydroxylanisole (BHA), Butylatedhydroxyltoluene (BHT), $\alpha$-Tocopherol, $\beta$-carotene, linoleic acid, polyoxyethylene sorbitan monopalmitate (Tween-40), Neocuproine,2,2>azino-bis(3-ethylbenzothiazoline-6-sulfonicacid)diammoniumsalt (ABTS), Trichloroacetic acid (TCA), Ethylenediaminetetraacetic acid (EDTA), Nitro blue tetrazolium (NTB), Diméthyl sulfoxyde (DMSO), Sulforhodamine B (SRB), and were obtained from Sigma Chemical Co. j(Sigma-Aldrich $\mathrm{GmbH}$, Stern-heim, Germany), while Sodium Carbonate, Aluminum Nitrate, Iron (III) chloride $\left(\mathrm{FeCl}_{3}\right)$, Iron (II) chloride, Sodium bicarbonate, Potassium acetate, were obtained from Biochem Chemopharma. All other chemicals and solvents were of analytical grade.

\section{Determination of total bioactive compounds}

\section{Determination of total phenolic content (TPC)}

The total phenolic content in the extract was determined spectrophotometry via Folin-Ciocalteu reagent according to the method of Muller et al. [19], with a minor modification. In doing so, $1 \mathrm{mg}$ of extract was dissolved in a volume of $1 \mathrm{~mL}$ of methanol, then $20 \mu \mathrm{L}$ of extract at various concentrations were mixed with $100 \mu \mathrm{L}$ of Folin-Ciocalteu reagent diluted to $1: 10$ and $75 \mu \mathrm{L}$ of sodium carbonate solution $(75 \mathrm{~g} / \mathrm{L})$ in the wells of a 96-well microplate in the dark at room temperature. After $2 \mathrm{~h}$, the absorbance was measured at $740 \mathrm{~nm}$. A blank is prepared in the same way by replacing the extract with the solvent used (Methanol). Total polyphenols was quantified by employing a gallic acid calibration curve at different concentrations. The total content of phenolic compounds was expressed as micrograms of gallic acid equivalents per milligram of extract ( $\mu \mathrm{g}$ EAG/mg). All bio-activity measurements were carried out using a 96-well microplate reader (Perkin Elmer Enspire, USA).

\section{Determination of total flavonoid Content (TFC)}

The establishment of total flavonoid content of the extract was based on the method described by Topçu et al. [20], with slight modifications for determination on a 96-well microplate. Accordingly, $1 \mathrm{mg}$ of extract was dissolved in a volume of $1 \mathrm{~mL}$ of methanol. Subsequently, $130 \mu \mathrm{L}$ $(\mathrm{MeOH}), 10 \mu \mathrm{L}$ of potassium acetate $\left(\mathrm{CH}_{3} \mathrm{COOK}\right)$ prepare in water and $10 \mu \mathrm{L}$ of the aqueous solution of aluminium nitrate $\left(\mathrm{Al}\left(\mathrm{NO}_{3}\right)_{2}, 9 \mathrm{H}_{2} \mathrm{O}\right)$ was added to a volume of $50 \mu \mathrm{L}$ of extract at various dilutions. The absorbance was read at $415 \mathrm{~nm}$, after incubation at room temperature for $40 \mathrm{~min}$. A blank sample was prepared by replacing the reagents with methanol $(50 \mu \mathrm{L}$ extract $+150 \mu \mathrm{L}$ methanol $)$. The quantification of flavonoids was deduced from a calibration range established with quercetin, as a positive control. The results were evaluated as micrograms of quercetin equivalents per milligram of extract ( $\mu \mathrm{g} \mathrm{EQ} / \mathrm{mg})$.

\section{Determination of antioxidant activity}

\section{DPPH` scavenging assay}

The free anti-radical activity was determined spectrophotometry via DPPH assay [21]. Briefly, $40 \mu \mathrm{L}$ of $\mathrm{MeOH}$ extract solution at various concentrations was added to $160 \mu \mathrm{L}$ of DPPH $(0.1 \mathrm{mM})$. The reaction mixture was then shaken vigorously and the absorbance of the remaining DPPH was measured at $517 \mathrm{~nm}$ after $30 \mathrm{~min}$. BHA and BHT were used as antioxidant standards for activity comparison. The scavenging capability of DPPH radical was calculated using the following equation:

$$
\text { DPPH scavenging effect }(\%)=\frac{\mathrm{A}_{\text {Control }}-\mathrm{A}_{\text {Sample }}}{\mathrm{A}_{\text {Control }}} \times 100
$$

- Abs control is the absorbance of the reaction containing only the reagents.

- Abs Extract is the absorbance of the reaction containing the reagents and the extract.

The results were given in the form of $\mathrm{IC}_{50}$ value $(\mu \mathrm{g} / \mathrm{mL})$ corresponding to the concentration of $50 \%$ inhibition.

\section{ABTS cation radical Assay}

The $\mathrm{ABTS}^{\cdot+}$ scavenging activity was derived according to the method of Re et al. [22]. The cation radical ABTS was generated by mixing $7 \mathrm{mM}$ of an aqueous solution of ABTS with $2.45 \mathrm{mM}$ of potassium persulfate, the whole was then stored protected from light and at room temperature for $16 \mathrm{~h}$ before use. The solution obtained was subsequently diluted with ethanol to obtain an absorbance of $0.700 \pm 0.025$ 
at $734 \mathrm{~nm}$. After this, $160 \mu \mathrm{L}$ of ABTS solution was added to $40 \mu \mathrm{L}$ of methanol extract solution at different concentrations. After $10 \mathrm{~min}$, the absorbance was measured at $734 \mathrm{~nm}$. Methanol was used as a control; BHA and BHT were used as antioxidant standards for the comparison of extract activity.

The scavenging capacity of the $\mathrm{ABTS}^{++}$was calculated using the following equation:

$$
\mathrm{ABTS}^{++} \text {Scavenging effect }(\%)=\frac{\mathrm{A}_{\text {Control }}-\mathrm{A}_{\text {Sample }}}{\mathrm{A}_{\text {Control }}} \times 100
$$

\section{Superoxide radical scavenging assay by alkaline DMSO}

The scavenging activity of superoxide radicals by alkaline DMSO was obtained by the method of Rao and Kunchandy [23], with the reduction of NBT by superoxide being assessed in the presence and in the absence of extracts. In accomplishing this, the reaction mixture containing NBT $(1 \mathrm{mg} / \mathrm{mL}$ in distilled water) and $40 \mu \mathrm{L}$ of extract at various dilutions were added to $130 \mu \mathrm{L}$ of alkaline DMSO $(1 \mathrm{~mL}$ of DMSO containing, $5 \mathrm{mM} \mathrm{NaOH}$ in $0.1 \mathrm{~mL}$ of water) to give a final volume of $200 \mu \mathrm{L}$ and the absorbance was measured at $560 \mathrm{~nm}$ using a microplate reader (Perkin Elmer Enspire, USA). The decrease in absorbance at $560 \mathrm{~nm}$ with antioxidants indicates the consumption of the superoxide generated, and the percentage of scanning was calculated using the following formula:

$$
\text { Inhibition }(\%)=\frac{\mathrm{A}_{\text {Sample }}-\mathrm{A}_{\text {Contro }}}{\mathrm{A}_{\text {Sample }}} \times 100
$$

\section{Reducing power assay}

The reducing power of the tested extract was established according to the method of Aicha Bouratoua [24]. In order to determine the reducing power activity, $10 \mu \mathrm{L}$ of serial diluted sample were added into a 96 well round-bottomed plate. Following this, $40 \mu \mathrm{L}$ of $0.2 \mathrm{M}$ phosphate buffer (pH 6.6) and $50 \mu \mathrm{L}$ of potassium ferricyanide (1\%), were added to each well and the plate was incubated at $50^{\circ} \mathrm{C}$ for $20 \mathrm{~min}$. Finally, $50 \mu \mathrm{L}$ of TCA $(10 \%)$ and distilled water $(40 \mu \mathrm{L})$ and $10 \mu \mathrm{L}$ of ferric chloride $(0.1 \%)$ were added into each well in order to measure the reducing power activity. After this, the absorbance was measured in a microplate reader (Perkin Elmer Enspire, USA) at $700 \mathrm{~nm}$. Note: higher absorbance of the reaction mixture indicates greater reducing power.

\section{$\beta$-carotene/linoleic Acid bleaching assay}

The bleaching activity of $\beta$-carotene was evaluated using the method described by Marco [25]. A mass of $0.5 \mathrm{mg}$ of $\beta$-carotene dissolved in $1 \mathrm{ml}$ of chloroform was added to a volume of $25 \mu \mathrm{L}$ of linoleic acid and $200 \mathrm{mg}$ of Tween 40 , giving an emulsifying mixture. After evaporation of the chloroform in vacuo, $50 \mathrm{~mL}$ of distilled water saturated with oxygen was added with vigorous stirring. The absorbance of the solution was then adjusted between 0.8-09 nm. $160 \mu \mathrm{L}$ of this solution was added to $40 \mu \mathrm{L}$ of extract solution at different concentrations. Absorbance was measured at $470 \mathrm{~nm}$ using a 96-well microplate reader (Perkin Elmer Enspire, USA). The emulsion system was subsequently incubated for $2 \mathrm{~h}$ at $50^{\circ} \mathrm{C}$, while a blank devoid of $\beta$-carotene, was prepared for the background subtraction. BHA and BHT were used as standards. The bleaching rate $(\mathrm{R})$ of $\beta$-carotene was calculated according to the following equation:

$$
\mathrm{R}=(\ln \mathrm{a} / \mathrm{b}) / \mathrm{t}
$$

The antioxidant activity (AA) was derived in terms of percent of inhibition relative to the control, using the following equation:

$$
\text { AA }(\%)=\frac{\mathrm{R}_{\text {Control }}-\mathrm{R}_{\text {Sample }}}{\mathrm{R}_{\text {Control }}} \times 100
$$

\section{Cupric reducing antioxidant capacity (CUPRAC)}

The antioxidant activity by cupric reduction was assessed according to the method of Apak et al. [26]. A reaction mixture containing $40 \mu \mathrm{L}$ of the extract at different concentrations, $50 \mu \mathrm{L}$ of a copper (II) chloride solution, $50 \mu \mathrm{L}$ of neocuproin alcoholic solution and $60 \mu \mathrm{L}$ of ammonium acetate aqueous buffer at $\mathrm{pH} 7$ was placed in each well of a 96-unit microplate. After $30 \mathrm{~min}$, the absorbance was recorded at $450 \mathrm{~nm}$. The results were calculated as $A_{0.5}(\mu \mathrm{g} / \mathrm{mL})$ corresponding to the concentration indicating 0.50 of absorbance. BHA and BHT were used as antioxidant standards.

\section{Determination of in-vitro Antiproliferative Activity Cell Culture}

C6 (Rattus norvegicus brain glioma) and HT29 (Homo sapiens colorectal adenocarcinoma) cell lines were cultured in DMEM (Sigma-Aldrich; St. Louis, MO). All media were supplemented with $10 \%$ fetal bovine serum (FBS) and $1 \%$ Pen/Strep. Cells were grown at $37^{\circ} \mathrm{C}$ in a humidified atmosphere with $5 \% \mathrm{CO}_{2}$. The plant extract was dissolved in double distillated water, and stock solutions were filtered using $0.45 \mu \mathrm{m}$ syringe filters (Minisart, Sartorius Stedim Biotech, Goettingen, Germany). Stock solutions were kept at $4^{\circ} \mathrm{C}$ for further use and diluted to desired concentrations with media before treatment.

\section{Cytotoxicity Assay}

Sulforhodamine B (SRB) Assay was used to determine percent cell viability of cell lines (C6, HT29) treated with various concentrations of Centaurea maroccana extract as described in Vichai and Kirtikara [27]. Briefly, 7500 cells were seeded per well in a 96-well plate (flat bottom). After $24 \mathrm{~h}$ incubation, cells were treated with various concentrations of the extract ( $n$-butanolic extract of Centaurea maroccana) and further incubated for $72 \mathrm{~h}$. The cells were then fixed with $10 \%$ trichloroacetic acid (TCA) for 1.5 hours at $4^{\circ} \mathrm{C}$ and washed with $\mathrm{ddH}_{2} \mathrm{O}$ for 4 times. Following this, $0.4 \%$ SRB dye (dissolved in $1 \%$ acetic acid) was added to each well in the dark and the plates were incubated for an additional $30 \mathrm{~min}$ at room temperature. After washing with $\mathrm{ddH}_{2} \mathrm{O}$ for 4 times, the plates were dried and the dye was solubilized by incubating the cells with $10 \mathrm{mM}$ Tris base solution for 15 minutes on a shaker. Spectrophotometric reading was then performed at $565 \mathrm{~nm}$ using a Multiskan FC microplate reader (Thermo Scientific, MA, USA). OD values were used for analysis. 


\section{Statistical analysis}

All data on all activity tests were the average of triplicate analyses. The data were recorded as mean \pm standard deviation (SD). Significant differences between means were determined by Student's-test, $\mathrm{p}$ values $<0.05$ were regarded as significant.

\section{RESULTS AND DISCUSSION}

\section{Total phenolic content}

Phenolic compounds are secondary metabolites that have antioxidant, anti-inflammatory, antimicrobial, and anti-cancer activities [28]. Research indicates that phenolic content correlates with antioxidant activity [29]. The antioxidant activity of phenolic contents comes about due to their redox properties that permit them to scavenge radicals, metal chelators, singlet oxygen quenchers, hydrogen donors, and reducing agents [30]. Hence, it is important to quantify and assess the effect of the phenolic content on the antioxidant activity in our extract.

In our work, the total phenolic content of BECM was determined using the Folin-Ciocalteu reagent and expressed as micrograms of gallic acid equivalents per milligram of extract. The derived valued was calculated from the linear regression equation of a standard curve $(y=0.0056$ $\left.\mathrm{x}+0.0948, \mathrm{R}^{2}=0.9953\right)$. Results show that the $n$-butanol extract of Centaurea maroccana (BECM), in particular, had high phenolic content at 242.30 $\pm 1.44 \mu \mathrm{g} \mathrm{GAE} / \mathrm{mg}$.

\section{Total flavonoids content}

Flavonoids are naturally occurring polyphenols existing in almost all plant resources [31]. The high antioxidant potential of flavonoids lies in their ability to eliminate free radicals and injurious ROS that arise from several cellular activities and lead to oxidative stress [32]. In the present study, the concentrations of flavonoids was determined using the aluminum chloride colorimetric method and was calculated from the linear regression equation of a standard curve of quercetin $\left(y=0.0098 x+0.0623, R^{2}=0.985\right)$. The quantification is expressed as micrograms quercetin equivalents per milligram of extract. The results reveal that the amount of flavonoids in the n-butanol extract of BECM is $23.34 \pm 1.28 \mu \mathrm{g} \mathrm{QE} / \mathrm{mg}$.

\section{Antioxidant properties}

In this study, the antioxidant activity of an $n$ - butanol extract of Centaurea maroccana was established through by applying six in-vitro assays: DPPH radical scavenging, ABTS cation radical scavenging, superoxide radical scavenging assay by alkaline (DMSO), $\beta$-carotene-linoleic acid bleaching, cupric reducing antioxidant capacity (CUPRAC) and reducing power activity.

The DPPH assay has frequently been used for assessing the anti-oxidative potential of natural products as it is considered a rapid and least cost method [33]. DPPH at room temperature is a stable free-radical that receives an electron/ hydrogen radical to become a stable diamagnetic molecule [34]. Antioxidants interact with DPPH, changing its deep violet color to yellow.
The ability of the BECM extract to scavenge the DPPH radical is shown in Table 1. The reference compounds used in this test are BHT and BHA. It can be seen that a significant decrease $(p<0.05)$ in the concentration of DPPH radicals was exhibited by the extract and standards. In our work, the $\mathrm{IC}_{50}$ value of BECM extract was found to be $12.09 \pm 0.54 \mu \mathrm{g} / \mathrm{mL}$. This figure is higher than that of the BHT standard $(22.32 \pm 1.19 \mu \mathrm{g} / \mathrm{mL})$, but lower than the $\mathrm{IC}_{50}$ of BHA at $5.73 \pm 0.41 \mu \mathrm{g} / \mathrm{mL}$. Thus, these results reveal that the n-butanol extract has a high DPPH radical scavenging effect that is comparable with the standards.

Table 1. DPPH radical scavenging activity of BECM and the standards butylated hydroxy toluene (BHT) and butylated hydroxyl lanisole (BHA)

\begin{tabular}{|c|c|c|c|}
\hline \multirow{2}{*}{$\begin{array}{c}\text { Concentration } \\
\mu \mathrm{g} / \mathrm{mL}\end{array}$} & \multicolumn{3}{|c|}{$\%$ Inhibition in DPPH Assay } \\
\cline { 2 - 4 } & BECM & BHT & BHA \\
\hline 3.125 & $17.12 \pm 1.57$ & $11.69 \pm 1.88$ & $28.95 \pm 1.16$ \\
\hline 6.25 & $26.77 \pm 3.42$ & $22.21 \pm 1.30$ & $54.33 \pm 1.59$ \\
\hline 12.5 & $50.35 \pm 3.03$ & $37.12 \pm 1.80$ & $76.76 \pm 1.65$ \\
\hline 25 & $84.70 \pm 1.49$ & $52.63 \pm 2.70$ & $84.09 \pm 0.35$ \\
\hline 50 & $84.95 \pm 0.23$ & $56.02 \pm 0.53$ & $87.53 \pm 0.82$ \\
\hline 100 & $85.76 \pm 0.95$ & $83.60 \pm 0.23$ & $87.73 \pm 0.15$ \\
\hline 200 & $86.31 \pm 1.67$ & $87.28 \pm 0.26$ & $88.43 \pm 0.23$ \\
\hline IC $_{50} \mu \mathrm{g} / \mathrm{mL}$ & $12.09 \pm 0.54$ & $22.32 \pm 1.19$ & $5.73 \pm 0.41$ \\
\hline
\end{tabular}

The ABTS radical scavenging method is a most dependable method for determining free radicals destruction [35]. The $\mathrm{ABTS}^{\cdot+}$ chromophore is generated during the reaction of ABTS and potassium persulfate through the transformation of ABTS into a radical cation. The color of this radical cation is blue and absorbs light at $734 \mathrm{~nm}$ [36].

Table 2 shows that $\mathrm{ABTS}^{{ }^{++}}$cation radical was significantly inhibited at all concentrations tested. However, at the high concentration of $200 \mu \mathrm{g} / \mathrm{mL}$, the percentage inhibition by the BECM reached $93.05 \pm 0.65 \%$. This outcome is similar to BHT and BHA $(96.68 \pm 0.39 \%$ and $95.39 \pm 2.62 \%$, respectively). Hence, good $\mathrm{ABTS}^{-+}$free-radical scavenging activity was revealed by $\mathrm{BECM}$ at $\mathrm{IC}_{50}=15.13 \pm 0.87 \mu \mathrm{g} / \mathrm{mL}$, in relation to the standards $\mathrm{BHT}\left(\mathrm{IC}_{50}=1.29 \pm 0.30 \mu \mathrm{g} / \mathrm{mL}\right)$ and $\mathrm{BHA}\left(\mathrm{IC}_{50}=1.81 \pm 0.10 \mu \mathrm{g} / \mathrm{mL}\right)$.

Table 2. Free radical scavenging activity of $n$-butanol extract of Centaurea maroccana on ABTS (2,2-azinobis-3-ethylbenzothiazoline-6-sulfonic)

\begin{tabular}{|c|c|c|c|}
\hline \multirow{2}{*}{$\begin{array}{c}\text { Concentration } \\
\mu \mathrm{g} / \mathrm{mL}\end{array}$} & \multicolumn{3}{|c|}{$\%$ Inhibition in ABTS Assay } \\
\cline { 2 - 4 } & BECM & BHA & BHT \\
\hline 3.125 & $12.52 \pm 2.61$ & $83.42 \pm 4.09$ & $59.22 \pm 0.59$ \\
\hline 6.25 & $24.68 \pm 1.70$ & $93.52 \pm 0.09$ & $78.55 \pm 3.43$ \\
\hline 12.5 & $47.49 \pm 3.09$ & $93.58 \pm 0.09$ & $90.36 \pm 0.00$ \\
\hline 25 & $73.77 \pm 2.88$ & $93.63 \pm 0.16$ & $92.18 \pm 1.27$ \\
\hline 50 & $90.36 \pm 1.76$ & $93.63 \pm 0.95$ & $93.37 \pm 0.86$ \\
\hline 100 & $92.73 \pm 1.42$ & $94.20 \pm 0.90$ & $94.87 \pm 0.87$ \\
\hline 200 & $93.05 \pm 0.65$ & $95.39 \pm 2.62$ & $96.68 \pm 0.39$ \\
\hline IC $_{50} \mu \mathrm{g} / \mathrm{mL}$ & $15.13 \pm 0.87$ & $1.81 \pm 0.10$ & $1.29 \pm 0.30$ \\
\hline
\end{tabular}

BHT and BHA were used as standards 
The superoxide radical is the precursor of more reactive species and is recognized as one of the most damaging species for cellular constituents [37]. The super oxide scavenger capacity of antioxidants present in the extract is determined by the decrease in absorbance at $560 \mathrm{~nm}$. Table 3 shows that the BECM inhibits the formation of the super oxide anion radical generated in vitro by the DMSO alkaline system in a dose-dependent manner. The maximum inhibition of NBt reduction by super oxide $(91.57 \pm 0.51 \%)$ was observed at the high concentration of $200 \mu \mathrm{g} / \mathrm{mL}$ and was comparable to Tannic acid and $\alpha$-Tocopherol standards $(97.54 \pm 0.68 \%, 96.86 \pm 1.53 \%$, respectively). Of significance, however, is that the butanolic extract of Centaurea maroccana has a stronger super oxide scavenging activity $\left(\mathrm{IC}_{50}=4.50 \pm 0.33\right)$ than the two standards used $\left(\mathrm{IC}_{50}=<\right.$ 3.125 and $<3.125$ ).

Table 3. Superoxide radical scavenging assay by alkaline DMSO of butanolic extract of Centaurea maroccana

\begin{tabular}{|c|c|c|c|}
\hline \multirow{2}{*}{$\begin{array}{c}\text { Concentration } \\
\mu \mathrm{g} / \mathrm{mL}\end{array}$} & \multicolumn{3}{|c|}{ \% Inhibition in DMSO alcalin assay } \\
\cline { 2 - 4 } & BECM & Tannic acid & $\mathrm{a}$-Tocopherol \\
\hline 3.125 & $47.73 \pm 4.47$ & $83.58 \pm 1$ & $70.09 \pm 1.84$ \\
\hline 6.25 & $64.83 \pm 3.77$ & $88.35 \pm 0.61$ & $79.07 \pm 2.54$ \\
\hline 12.5 & $74.40 \pm 2.73$ & $92.66 \pm 0.42$ & $85.1 \pm 1.36$ \\
\hline 25 & $80.66 \pm 1.08$ & $94.98 \pm 0.85$ & $89.48 \pm 0.88$ \\
\hline 50 & $85.97 \pm 1.03$ & $96.53 \pm 0.23$ & $94.76 \pm 0.28$ \\
\hline 100 & $88.28 \pm 0.52$ & $96.95 \pm 0.81$ & $96.62 \pm 0.29$ \\
\hline 200 & $91.57 \pm 0.51$ & $97.54 \pm 0.68$ & $96.86 \pm 1.53$ \\
\hline $\mathrm{IC}_{50} \mu \mathrm{g} / \mathrm{mL}$ & $4.50 \pm 0.33$ & $<3.125$ & $<3.125$ \\
\hline
\end{tabular}

Tannic acid and a-Tocopherol were used as standards

Reducing power activity is used to assess the potential and the capacity of natural antioxidants to donate electrons [38], and there is a correlation between both the reducing properties and the existence of reductones [39]. These reductones convert yellowed coloured ferric iron $\left(\mathrm{Fe}^{3+}\right)$ to blue-green coloured ferrous iron $\left(\mathrm{Fe}^{2+}\right)$. Hence, reducing activity is determined by measuring the formation of Pearl's Prussian blue at $700 \mathrm{~nm}$. In this study, BECM had the power to reduce ferric ferricianide through increasing the absorbance via concentration. In our experiment, it exhibited an absorbance $(1.11 \pm 0.09)$ at the concentration of $50 \mu \mathrm{g} / \mathrm{mL}$, while the positive references BHT, BHA and Ascorbic Acid exhibited an absorbance of $0.43 \pm 0.02,3.53 \pm 0.19,3.87 \pm 0.27$, respectively, at the same concentration (Table 4). Thus, this extract $\left(\mathrm{A}_{0.50}=14,19 \pm 0,96 \mu \mathrm{g} / \mathrm{mL}\right)$ has a strong effect compared with BHA $\left(\mathrm{A}_{0.50}=>50\right)$, $\mathrm{BHA}\left(\mathrm{A}_{0.50}=8.41 \pm 0.67\right)$ and Ascorbic Acid $\left(\mathrm{A}_{0.50}=9.01 \pm 1.46\right)$.

We used the $\beta$-carotene-linoleic acid method to detect the inhibition level of lipid peroxidation [40]. In the $\beta$-carotene/ linoleic acid system, the oxidation of linoleic acid produces peroxyl free radicals owing to the abstraction of a hydrogen atom from the diallylic methylene groups of linoleic acid [41]. The resulting peroxy-free radicals participate in an emulsion attack upon the chromophore $\beta$-carotene, resulting in bleaching and loss of yellow color. The presence of antioxidant in this reaction mixture brings about the scavenging of radicals and the suppression of oxidation [28]. The results as shown in Table 5, and demonstrate that the lipid peroxidation inhibitory ability of the BECM increases significantly ( $p 0.05$ ) with increasing concentration. Here, the bleaching inhibitory activity of the extract tested at the highest concentration of $200 \mu \mathrm{g}$ reached a percentage of $83.48 \pm 3.97 \%$, whereas the positive standards of BHT reached $95.28 \pm 3.25 \%$, while that of BHA reached $99.76 \pm 0,91$. Thus, BECM has revealed itself to have interesting antioxidant activity in $\beta$-carotene bleaching, having an $\mathrm{IC}_{50}=11.08 \pm 0.30 \mu \mathrm{g} / \mathrm{mL}$, in comparison to the standards of BHT and BHA, which are in the following order: $1.05 \pm 0.01$ $\mu \mathrm{g} / \mathrm{mL}, 0.90 \pm 0.02 \mu \mathrm{g} / \mathrm{mL}$, respectively.

Table 4. Antioxidant activity of Centaurea maroccana by reducing power assay

\begin{tabular}{|c|c|c|c|c|}
\hline \multirow{2}{*}{$\begin{array}{c}\text { Concentration } \\
\mu \mathrm{g} / \mathrm{mL}\end{array}$} & \multicolumn{4}{|c|}{ Absorbance } \\
\cline { 2 - 5 } & BECM & BHA & BHT & Ascorbic Acid \\
\hline 0.78125 & $0.13 \pm 0.00$ & $0.09 \pm 0.00$ & $0.07 \pm 0.00$ & $0.09 \pm 0.00$ \\
\hline 1.5625 & $0.16 \pm 0.00$ & $0.11 \pm 0.01$ & $0.08 \pm 0.00$ & $0.11 \pm 0.00$ \\
\hline 3.125 & $0.17 \pm 0.02$ & $0.18 \pm 0.02$ & $0.10 \pm 0.01$ & $0.16 \pm 0.01$ \\
\hline 6.25 & $0.31 \pm 0.02$ & $0.36 \pm 0.04$ & $0.13 \pm 0.02$ & $0.33 \pm 0.04$ \\
\hline 12.5 & $0.44 \pm 0.02$ & $0.78 \pm 0.07$ & $0.22 \pm 0.04$ & $0.76 \pm 0.16$ \\
\hline 25 & $0.71 \pm 0.08$ & $1.74 \pm 0.07$ & $0.28 \pm 0.05$ & $2.02 \pm 0.23$ \\
\hline 50 & $1.11 \pm 0.09$ & $3.53 \pm 0.19$ & $0.43 \pm 0.02$ & $3.87 \pm 0.27$ \\
\hline $\mathrm{A}_{0.50} \mu \mathrm{g} / \mathrm{mL}$ & $14.19 \pm 0.96$ & $8.41 \pm 0.67$ & $>50$ & $9.01 \pm 1.46$ \\
\hline
\end{tabular}

$\mathrm{BHT}, \mathrm{BHA}$ and Ascorbic Acid were used as standards

Table 5. Antioxidant activity of Centaurea maroccana by the $\beta$-carotene-linoleic acid.

\begin{tabular}{|c|c|c|c|}
\hline \multirow{2}{*}{$\begin{array}{c}\text { Concentration } \\
\mu \mathrm{g} / \mathrm{mL}\end{array}$} & \multicolumn{3}{|c|}{ \% Inhibition in $\beta$-carotene assay } \\
\cline { 2 - 4 } & BECM & BHA & BHT \\
\hline 3.125 & $27.99 \pm 6.82$ & $84.23 \pm 1.14$ & $81.14 \pm 0.84$ \\
\hline 6.25 & $38.57 \pm 4.12$ & $90.11 \pm 0.68$ & $86.0 .9 \pm 1.04$ \\
\hline 12.5 & $51.40 \pm 5.36$ & $94.59 \pm 0.77$ & $87.52 \pm 4.24$ \\
\hline 25 & $69.15 \pm 2.36$ & $96.09 \pm 0.02$ & $91.67 \pm 0.52$ \\
\hline 50 & $77.19 \pm 3.07$ & $97.35 \pm 1.08$ & $94.11 \pm 0.42$ \\
\hline 100 & $83.34 \pm 2.28$ & $99.59 \pm 0.14$ & $94.41 \pm 0.32$ \\
\hline 200 & $83.48 \pm 3.97$ & $99.76 \pm 0.91$ & $95.28 \pm 3.25$ \\
\hline IC50 $\mu \mathrm{g} / \mathrm{mL}$ & $11.08 \pm 0.30$ & $0.90 \pm 0.02$ & $1.05 \pm 0.01$ \\
\hline
\end{tabular}

BHT and BHA were used as standards

The CUPRAC assay necessitates the use of comparatively standard equipment, where it is applied extensively to determine the antioxidant abilities of plant extracts, and gives quick and repeatable results [42]. The method is founded on the follow-up of the reduction in the augmented absorbance of Neocuproine ( $\mathrm{Nc}$ ) copper $\left(\mathrm{Cu}^{2+}\right)\left[\mathrm{Nc}_{2-} \mathrm{Cu}^{2+}\right]$, wherein the existence of an antioxidant agent reduces the complex (copper-neocuproine). This reaction is measured at $450 \mathrm{~nm}$. In our work, Centaurea maroccana extract revealed a strong CUPRAC reducing antioxidant ability with an $\mathrm{A}_{0.50}$ value equal to $9.80 \pm 0.43 \mu \mathrm{g} / \mathrm{mL}$. This is similar to the standards used, with BHT at $\mathrm{A}_{0.50}=9.62 \pm 0.87 \mu \mathrm{g} / \mathrm{mL}$, and BHA at $\mathrm{A}_{0.50}$ $=3.64 \pm 0.19 \mu \mathrm{g} / \mathrm{mL}$. At $200 \mu \mathrm{g} / \mathrm{mL}$ concentration, roughly same reducing activity was observed via extract and BHA at $3.48 \pm 0.13 \%$ and $3.93 \pm 0.01 \%$, respectively, while BHT was $2.32 \pm 0.28 \%$ (Table 6 ). 
Table 6. Antioxidant activity by the cupric reducing antioxidant capacity (CUPRAC) assay of Centaurea maroccana butanolic extract

\begin{tabular}{|c|c|c|c|}
\hline \multirow{2}{*}{$\begin{array}{c}\text { Concentration } \\
\mu \mathrm{g} / \mathrm{mL}\end{array}$} & \multicolumn{3}{|c|}{ Absorbance } \\
\cline { 2 - 4 } & BECM & BHA & BHT \\
\hline 3.125 & $0.23 \pm 0.00$ & $0.46 \pm 0.00$ & $0.19 \pm 0.01$ \\
\hline 6.25 & $0.39 \pm 0.06$ & $0.78 \pm 0.01$ & $0.33 \pm 0.04$ \\
\hline 12.5 & $0.59 \pm 0.02$ & $1.34 \pm 0.08$ & $0.66 \pm 0.07$ \\
\hline 25 & $1.02 \pm 0.06$ & $2.36 \pm 0.17$ & $1.03 \pm 0.07$ \\
\hline 50 & $1.76 \pm 0.14$ & $3.45 \pm 0.02$ & $1.48 \pm 0.09$ \\
\hline 100 & $2.49 \pm 0.29$ & $3.76 \pm 0.03$ & $2.04 \pm 0.14$ \\
\hline 200 & $3.48 \pm 0.13$ & $3.93 \pm 0.01$ & $2.32 \pm 0.28$ \\
\hline $\mathrm{A}_{0.50} \mu \mathrm{g} / \mathrm{mL}$ & $9.80 \pm 0.43$ & $3.64 \pm 0.19$ & $9.62 \pm 0.87$ \\
\hline
\end{tabular}

In summary, it can be deduced that the high levels of antioxidant activity exhibited by BECM were due to its richness of phenolic components and flavonoids, wherein phenolic components display antioxidant activity and play a significant role in stabilizing lipid peroxidation [43].

\section{Antiproliferative Activity}

After performing cytotoxicity screening using SRB Assay, we observed that n-butanolic extract of C. maroccana (BuOH ext.) significantly decreased percent viability of both cell lines (C6-glioma cell line, HT29-colorectal adenocarcinoma cell line) with increasing concentrations in the range of 50-300 $\mu \mathrm{g} / \mathrm{mL}$ (Fig. 1), and with highly similar cytotoxic effect. At $300 \mu \mathrm{g} / \mathrm{mL}$ concentration, cell viability was less than $50 \%$ compared to control cells (no treatment) in both $\mathrm{C} 6$ and HT29.

We then examined the effect of a combined treatment of BECM and cisplatin, a common chemotherapeutic drug, on these cancer cell lines. The outcome of this was that the combination of cisplatin with BECM treatment caused a slight decrease in cell viability for both cell lines compared to cisplatin treatment alone.

Boxplots showing percent cell viability of cell lines treated with indicated $n$-butanol extract concentrations (BuOH ext.) and/or cisplatin. Cytotoxicity was measured using SRB assay and $5 \mu \mathrm{M}$ cisplatin was used in these experiments. Blue boxplots indicate combination treatments with cisplatin.

\section{CONCLUSION}

In conclusion, the results of this study indicate that the n-butanolic extract of Centaurea maroccana possesses high total phenolic content and exhibits strong antioxidant activity through scavenging several free radicals. This synergistic antioxidant ability owing to the phenolic compounds present in the plant emphasizes the good correlation among antioxidant properties and phenolic content. Furthermore, we observed that the n-butanolic extract of Centaurea maroccana significantly decreases the percent viability of both cell lines (C6-glioma cell line, HT29-colorectal adenocarcinoma cell line) with increasing concentration. The present investigation showed that Centaurea maroccana can be considered as a source of bioactive compounds that could be used in the
C6

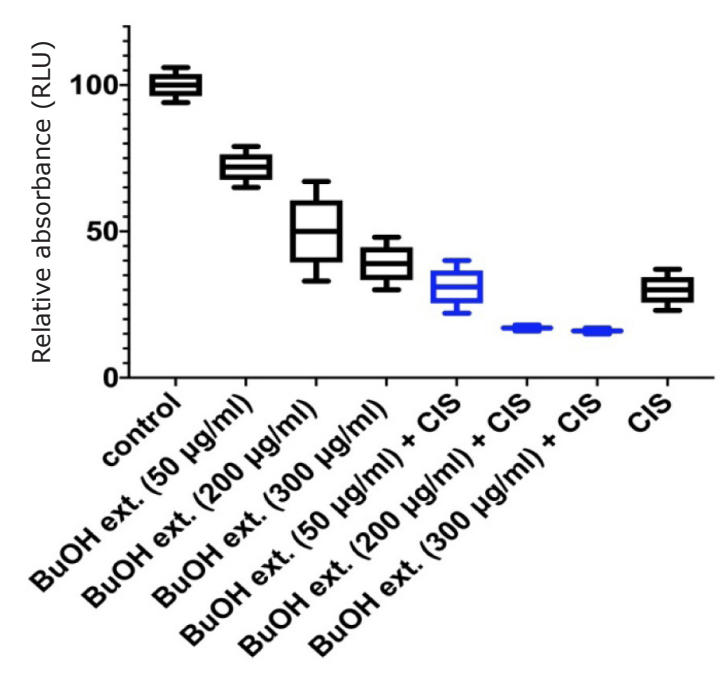

HT 29

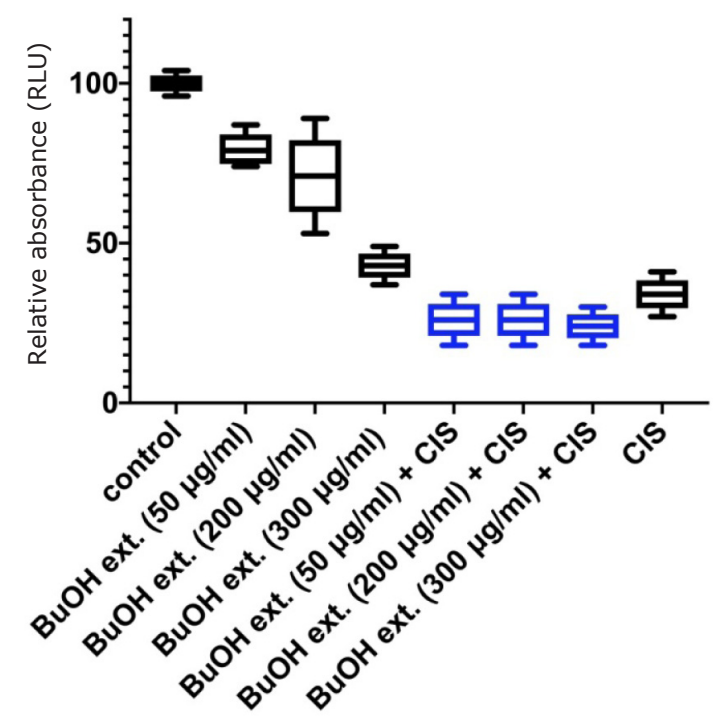

Figure 1. Cytotoxicity of $n$-butanol extract of Centaurea maroccana on C6 and HT29 cell lines

pharmaceutical and food industries. Further studies focusing on the isolation and identification of the principle bioactive molecules of antioxidant and antiproliferative activity are, however, needed.

\section{ORCID iDs}

Chawki Bensouici (Dhttps://orcid.org/0000-0003-4612-4642

\section{REFERNCES}

1. Adebiyi OE, Olayemi FO, Ning-Hua T, Guang-Zhi Z. In vitro antioxidant activity, total phenolic and flavonoid contents of ethanol extract of stem and leaf of Grewia carpinifolia. Beni-Suef Univ. J Basic Appl Sci. 2017;6(1):10-4.

2. Aktumsek A, Zengin G, Guler GO, Cakmak YS, Duran A. Antioxidant potentials and anticholinesterase activities of methanolic and aqueous extracts of three endemic Centaurea $\mathrm{L}$. species. Food Chem Toxicol. 2013;55:290-6. 
3. Djeridane A, Yousfi M, Nadjemi B, Boutassouna D, Stocker P, Vidal N Antioxidant activity of some algerian medicinal plants extracts containing phenolic compounds. Food Chem. 2006;97(4):654-60.

4. Noreen H, Semmar N, Farman M, McCullagh JSO. Measurement of total phenolic content and antioxidant activity of aerial parts of medicinal plant Coronopus didymus. Asian Pac J Trop Med. 2017;10(8):792-801.

5. Das N, Islam ME, Jahan N, Islam MS, Khan A, Islam MR, Parvin M S. Antioxidant activities of ethanol extracts and fractions of Crescentia cujete leaves and stem bark and the involvement of phenolic compounds. BMC Complement Altern Med. 2014;14(45).

6. Ayad R, Ababsa ZA, Belfadel FZ, Akkal S, León F, Brouard I, Medjroubi K. Phytochemical and biological activity of Algerian Centaurea melitensis. Int J Med Arom Plants. 2012;2:151-4.

7. Louaar S, Zellagui A, Gherraf N, Medjroubi K, Derbre S, Seguin E, et al. Antiradical activity of flavonoids from the Algerian Native Plant: Centaurea microcarpa Coss. et Dur. J Biol Act Prod Nat.2014;4(3):249-53.

8. Aktumsek A, Zengin G, Guler GO, Cakmak YS, Duran A. Screening for in vitro antioxidant properties and fatty acid profiles of five Centaurea L. species from Turkey flora. Food Chem Toxicol. 2011;49(11):2914-20.

9. Khammar A, Djeddi S. Pharmacological and biological properties of some Centaurea species. Eur J Sci Res. 2012;84:398-416.

10. Zengin G, Cakmak YS, Guler GO, Aktumsek A. In vitro antioxidant capacities and fatty acid compositions of three Centaurea species collected from Central Anatolia region of Turkey. Food Chem Toxicol. 2010;48(10):2638-41.

11. Erel SB, Karaalp C, Bedir E, Kaehlig H, Glasl S, Khan S, Krenn L. Secondary metabolites of Centaurea calolepis and evaluation of cnicin for anti-inflammatory, antioxidant, and cytotoxic activities Pharm Biol. 2011;49(8):840-9.

12. Güven K, Çelik S, Uysal I. Antimicrobial activity of Centaurea species. Pharm Biol. 2005;43(1):67-71.

13. Koca U, Özçelik B. Antiviral, antibacterial, and antifungal activities of Centaurea tchihatcheffii extracts. Turk J Pharm Sci. 2009;6(2):125-34

14. Erol-Dayi Ö, Pekmez M, Bona M, Aras-Perk A, Arda N. Total phenolic contents, antioxidant activities cytotoxicity of three Centaurea species: C. calcitrapa subsp. calcitrapa, C. ptosimopappa and C. spicata. Free Rad Antiox. 2011;1(2):31-6.

15. Mezache N, Bendjeddou D, Satta D, Mekkiou R, Benayache S, and Benayache F. Secondary metabolites from Centaurea lippii. Chem Nat Compd. 2010;46:801-2.

16. Grafakou ME, Djeddi S, Hamel T, Skaltsa H. Secondary metabolites from the aerial parts of Centaurea papposa (Coss.) Greuter. Biochem Syst Ecol. 2018;76:15-22.

17. Bicha S, Bentamene A, Benaissa O, Benayache S, Garcia VP, Leon F, et al. Flavonoid aglycones from Centaurea maroccana. Chem Nat Compd. 2011;47:105-6.

18. Quezel P, Santa S. Nouvelle Flore de l'Algérie et des régions désertiques méridionales. Paris: Centre National de La Recherche Scientifique (CNRS) ; 1963:1016-32.

19. Muller L, Gnoyke S, Popken AM, Bohm V. Antioxidant capacity and related parameters of different fruit formulations. LWT Food Sci Technol. 2010;43(6):992-9.

20. Topçu G, Ay A, Bilici A, Sarıkürkcü C, Öztürk M, Ulubelen A A new flavone from antioxidant extracts of Pistacia terebinthus. Food Chem. 2007;103(3):816-22.

21. Blois MS. Antioxidants determination by the use of a stable free radical. Nature. 1958;26:1199-200.

22. Re R, Pellegrini N, Proteggente A, Pannala A, Yang M, Rice-Evans C. Antioxidant activity applying an improved ABTS radical cation decolorization assay. Free Radic Biol Med. 1999;26 (9-10):1231-7.

23. Kunchandy E, Rao MNA. Oxygen radical scavenging activity of curcumin. Int J Pharm. 1990;58(3):237-40.

24. Bouratoua A, Khalfallah A, Bensouici C, Kabouche Z, AlabdulMagi A, Harakat D, et al. Chemical composition and antioxidant activity of aerial parts of Ferula longipes Coss. ex Bonnier and Maury. Nat Prod Res. 2017;32(16):1873-80.

25. Marco GJ. A rapid method for evaluation of antioxidants. J Am Oil Chem Soc. 1968;45:594-8.
26. Apak R, Güçlü K, Ozyürek M, Karademir SE. Novel total antioxidant capacity index for dietary polyphenols and vitamins $\mathrm{C}$ and $\mathrm{E}$, using their cupric ion reducing capability in the presence of neocuproine: CUPRAC method. J Agric Food Chem. 2004;52(26):7970-81.

27. Vichai V, Kirtikara K. Sulforhodamine B colorimetric assay for cytotoxicity screening. Nat. Protoc. 2006;1(3):1112-6.

28. Tel-Çayan G, Deveci E, Çayan F, Duru ME. Comparative assessment of phytochemical composition, antioxidant and anticholinesterase activities of two Basidiomycota Truffle Fungi from Turkey. Marmara Pharm J. 2018;22 (1):59-65.

29. Tel G, Apaydın M, Duru ME, Öztürk M. Antioxidant and cholinesterase inhibition activities of three Tricholoma species with total phenolic and flavonoid contents: The edible mushrooms from anatolia. Food Anal Methods. 2011; 5(3):495-504.

30. Phang CW, Sri-Nurestri AM, Halijah I. Antioxidant potential, cytotoxic activity and total phenolic content of Alpinia pahangensis rhizomes. BMC Complement Altern Med. 2013;13(1).

31. Nishaa S, Vshnupriya M, Gopalakrishnan VK. Qualitative assessment of ethanolic extract of Maranta arundinacea L.rhizome using HPLC. Int Res J Pharm.2013;4(2):76-83.

32. Kalim MD, Bhattacharyya D, Banerjee A, Chattopadhyay S. Oxidative DNA damage preventive activity and antioxidant potential of plants used in Unani system of medicine. BMC Complement Altern Med. 2010;10(1).

33. Krishnamoorthy M, Sasikumar J, Shamna R, Pandiarajan C, Sofia P, Nagarajan B. Antioxidant activities of bark extract from mangroves, Bruguiera cylindrica (L.) Blume and Ceriops decandra Perr. Indian J Pharmacol.2011;43(5):557.

34. Ansari AQ, Syed Abrar A, Waheed MA, Sayyed Juned A. Extraction and determination of antioxidant activity of Withania somnifera Dunal. Eur J Exp Biol. 2013;3(5):502-7.

35. Chandrashekhar HR, Venkatesh P, Arumugam M, Vijayan P. Estimation of total phenols with special emphasis to antioxidant potentials of few Hypericum species. Pharmacologyonline. 2009; 1:680-7.

36. Lalhminghlui K, Jagetia GC. Evaluation of the free-radical scavenging and antioxidant activities of Chilauni, Schima wallichii Korth in vitro. Future Sci OA. 2018;4(2).

37. Kumar RS, Rajkapoor B, Perumal P. Antioxidant activities of Indigofera cassioides Rottl. Ex. DC. using various in vitro assay models. Asian Pac J Trop Biomed. 2012; 2(4):256-61.

38. Jamuna S, Paulsamy S and Karthika K. Screening of in vitro antioxidant activity of methanolic leaf and root extracts of Hypochaeris radicata L. (Asteraceae). J Appl Pharm Sci. 2012; 02(07):149-54.

39. Saha M, Hasan S, Akter R, Hossain M, Alam M, Alam M, Mazumder M. In vitro free radical scavenging activity of methanol extract of the leaves of Mimusops elengi Linn. Bangladesh J Vet Med. 2008;6(2):197-202.

40. Öztürk M, Duru ME, Kivrak Ş, Mercan-Doğan N, Türkoglu A, Özler MA. In vitro antioxidant, anticholinesterase and antimicrobial activity studies on three Agaricus species with fatty acid compositions and iron contents: A comparative study on the three most edible mushrooms. Food Chem Toxicol. 2011;49(6):1353-60.

41. Laggoune S, Öztürk M, Erol E, Duru ME, Abaza I, Kabouche A, Kabouche Z. Chemical composition, antioxidant and antibacterial activities of the essential oil of Mentha spicata L. from Algeria. J Mater Environ Sci. 2016;7:4205-13.

42. Tusevski O, Kostovska A, Iloska A, Trajkovska L, Simic S. Phenolic production and antioxidant properties of some Macedonian medicinal plants. Cent Eur J Biol. 2014;9(9):888-900.

43. Vindhya K, Leelavathi S. Evaluation of antioxidant properties and total phenolic content of Gardenia gummifera Linn. Int J Pharm Sci Rev Res. 2015;32 (1):255-61. 